\title{
Un capítulo de la historia de la escritura en América: la enseñanza de las primeras letras a los indios en el siglo XVI
}

Sergio Rodríguez Lorenzo

Universidad de Sevilla

La escritura ha sido, tal vez, el invento más importante de la historia de la humanidad. El proceso de colonización del Nuevo Mundo, que en gran parte fue realizado por innumerables misioneros, tuvo como uno de sus retos más difíciles de llevar a cabo la alfabetización de las poblaciones indígenas, aunque no siempre con un sentido meramente altruista. Distintos tipos de escuelas y colegios, diversos sistemas pedagógicos, fueron puestos en práctica a fin de que los indios aprendieran a leer y escribir. La intención de este trabajo es relatar y explicar los aspectos más interesantes de este capítulo de la historia de la escritura en América.

\section{Los orígenes de la evangelización}

Tras las noticias de Colón, los Reyes Católicos se apresuraron a legalizar las consecuencias del descubrimiento y la posesión de las tierras descubiertas, amparándose en el principio de la autoridad papal sobre las tierras poseídas por infieles. Del papa Alejandro VI (el valenciano Rodrigo de Borja) obtuvieron con relativa facilidad una serie de bulas en 1493, por las que se les atribuían todas las tierras a más de cien leguas al oeste de las islas Azores, autorizándolos para "someter a sus habitantes y moradores y convertirlos con el auxilio de la divina misericordia a la Fe Católica". ${ }^{.}$Una de las obligaciones morales a la que se comprometía la Corona hispana era la de enviar a aquellas tierras " [...] varones probos y temerosos de Dios, doctos, instruidos y experimentados para adoctrinar a los indígenas y habitantes dichos en la Fe Católica e imponérseles en las buenas costumbres, poniendo toda la debida diligencia en todo lo antedicho [...]". ${ }^{2}$

Desde el principio, pues, la empresa indiana se revistió de un profundo sentido religioso. Este deber moral de evangelizar los nuevos territorios no se limitaba a un abandono por parte de sus habitantes de sus religiones, o a un conocimiento superficial de la doctrina católica, porque el cristia-

1 Domínguez Ortiz, Antonio: Historia Universal: Edad Moderna, Madrid, 1989, pág. 53.

2 Bula Intercaetera (1493) en Ibot León: La Iglesia y los eclesiásticos en la empresa de Indias, Barcelona, 1973, pág. 130. 
nismo era más que una religión; se trataba de una forma de vida, de unas costumbres y usos propios: era una cultura. ${ }^{3} \mathrm{Y}$ como tal cultura necesitaba un proceso educativo para asimilarse, proceso que, dentro de sus numerosas facetas, incluía la alfabetización de la sociedad.

Ya en el segundo viaje de Colón, en 1493, la reina Isabel decidió que fuese acompañado por varios frailes para iniciar la evangelización. Se envió a fray Bernardo Boyl para que "[...] la palabra de Dios sea predicada y sembrada entre los naturales y habitantes de dichas tierras e islas que ahora no tienen conocimiento de la fe, para convertirlos en nuestra fe y religión cristiana, y enseñarlos e instruirlos en la práctica de los mandamientos del Señor $[\ldots] " .{ }^{4}$

Este proceso de alfabetización ha cumplido más de quinientos años, $\mathrm{y}$, sin embargo, no se ha valorado en su justa medida, y probablemente nunca podrá valorarse por muchos intentos que se hagan. ${ }^{5}$

\section{La primera gran dificultad: la lengua}

Para la enseñanza de la escritura y la lectura o, en un sentido más general, para evangelizar y aculturar a los indios hacía falta utilizar una lengua.

El panorama lingüístico del Nuevo Mundo era muy complicado. Multitud de lenguas con multitud de dialectos, todos diferentes entre sí y todos parecidos a la vez; estructuras gramaticales que nada tenían que ver con la lengua española, que por aquel entonces acababa de ser reglamentada. Sin embargo, el problema se subsanó en gran medida, dando lugar con el paso del tiempo no sólo a la difusión del castellano, sino a la pervivencia de muchas lenguas amerindias.

El primer sistema empleado por los misioneros para enseñar la doctrina cristiana fue el de las señales y gestos, pues desconocían la lengua indígena y aún carecían de intérpretes indios. ${ }^{6}$ La práctica fue demostrando a los misioneros que el sistema empleado hasta entonces planteaba muchas dificultades y no era eficaz para sus fines educativos. Decidieron cambiar de método, procurando una convivencia más estrecha con el indio.

3 Borges, Pedro: Misión y civilización en América, Madrid, 1986, pág. 226.

4 Bula Piis Fidelium (1493) en Ibot León: La Iglesia y los eclesiásticos..., pág. 130.

5 Ricard, Robert: La conquista espiritual de México, México, 1947, pág. 379.

6 Gimeno, Ana: El Consejo de Indias y la difusión del castellano, Valladolid, 1970, pág. 104. Mendieta, fray Jerónimo de: Historia Eclesiástica Indiana, Madrid, 1973, Libro III, Capítulo XV, pág. 132. Ricard: La conquista espiritual..., pág. 130. 
Este cambio nos lo relata fray Juan de Torquemada en su Monarquía Indiana y fray Jerónimo de Mendieta en su Historia Eclesiástica:

“[...] y así fue, que dejando a ratos la Gravedad, y Autoridad de sus personas, se ponían a jugar con ellos con pajuelas o pedrezuelas los ratillos que tenían de descanso, y esto hacían por quitarles el empacho con la comunicación; y traían siempre papel y tinta en las manos, y en oiendo el Vocablo al indio, lo escrivían, y el propósito que lo dijo. A la tarde juntábanse los Religiosos, y comunicavan los unos a los otros sus escritos, y lo mejor que podían conformava a aquellos Vocablos al Romance que les parecía convenir. Y acontecioles que lo que oi les parecía que avían entendido, mañana les parecía no ser así."’

En esta ocasión el método había partido de los propios misioneros, que intentaron aprender la lengua indígena para de ese modo poder explicar a los niños el significado de las oraciones que les enseñaban en latín o en castellano. ${ }^{8}$

A consecuencia de las noticias que iban llegando a la Península, el Consejo de Indias decidió tomar cartas en el asunto: el problema del idioma llegó a ser una cuestión oficial. Una real cédula de junio de 1550, dirigida a don Antonio de Mendoza, virrey de Nueva España, decía lo siguiente:

"Tratando de los medios que para este fin se podía tener, ha parecido que uno de ellos y el más principal sería dar orden como a esas gentes se les enseñare nuestra lengua castellana, porque sabida ésta, con más facilidad podían se adoctrinados en las cosas del Santo Evangelio.",

Con esta cédula se veía a la lengua castellana como un vehículo no sólo para el adoctrinamiento, sino para la asimilación cultural hispana. Se colocaba la enseñanza del idioma por delante de la religión - "siempre la lengua fue compañera del imperio", decía Nebrija-, aunque lo que se buscase en el fondo fuera un mejor camino para una buena evangelización. Era el principio de una campaña de la corona con la que pretendía la difusión del castellano mediante una serie de cédulas y mandamientos, más o menos exhortativos, que nunca se cumplieron en su totalidad. ${ }^{10}$

7 Torquemada, fray Juan de: Monarquía Indiana, México, 1979, Libro XV, Capítulo XIV, pág. 61. Mendieta: Historia Eclesiástica..., Libro III, Capítulo XVI, pág. 134.

8 Debe subrayarse la diferencia existente entre oración y catequesis. Para esta cuestión, véase Borges, Pedro (director): Historia de la Iglesia en Hispanoamérica, Madrid, 1993, pág. 515.

9 Konetzke, Richard: Colección de documentos para la historia de la formación social de Hispanoamérica (1493-1810), Madrid, 1953-64, tomo I, pág. 272.

10 Baudot, George: Utopía e Historia en México, Madrid, 1983, pág. 104. Ricard: La conquista espiritual..., pág. 138. 
El problema de la lengua se iba resolviendo con la formación de intérpretes indígenas; pero si bien este sistema ahorró dificultades, pronto se evidenció que la enseñanza incurría en graves errores ante los inconvenientes que traían consigo las malas traducciones. Para poner solución a este nuevo escollo, se instó a que los religiosos aprendiesen la lengua indígena para lograr, a la vez que un mayor acercamiento al indio, su definitiva evangelización. Ya en las instrucciones para el virrey Mendoza estaba presente la actitud comprensiva hacia las lenguas indígenas, aunque como medida provisional:

"Y porque para aprovechar en la conversión de los naturales es muy importante que entretanto ellos saben nuestra lengua, los religiosos y eclesiásticos se apliquen a saber su lengua y para ello la reduzcan a alguna Arte y manera fácil que se pueda aprender $[\ldots] "{ }^{\prime \prime 11}$

Esta nueva solución fue bien aceptada por el misionero, ya que era el primero en conocer la dificultad de enseñar el castellano. El padre Blas Valera opinaba sobre el asunto:

"Si los españoles que son de ingenio muy agudo y muy sabios en ciencias, no pueden, como ellos dicen, aprender la lengua general de Cuzco, ¿cómo se podrá hacer que los indios, no cultivados ni enseñados en letras, aprendan la lengua castellana?"12

Una dificultad añadida a la hora de aprender las lenguas amerindias era la gran cantidad de ellas que existían en una misma zona, y sus dialectos. ${ }^{13}$ Para dar buen cauce a esto, el padre José de Acosta proponía que no sería desacertado imponer una sola lengua general que ahorrase trabajo a los misioneros y beneficiase a la enseñanza de los indios. ${ }^{14}$ Fray Alonso de Zúñiga creía que esta medida de la lengua general no era imposible, pues ya los incas la habían puesto en práctica. ${ }^{15}$

Un texto muy bello, e ilustrativo de lo que fue el problema idiomático, es el contenido en una carta de fray Rodrigo de la Cruz al emperador en 1550:

11 Citada por Bayle, Constantino: España y la educación popular en América, Madrid, 1941, pág. 368. Baudot: Utopía..., pág. 104.

12 Citado en Gimeno: El Consejo de Indias..., pág. 110.

13 Baudot habla de no menos de cuarenta lenguas indígenas de uso corriente en el territorio mexicano sometido a los españoles. Baudot: Utopía..., pág. 102.

14 Paniagua Pascual, J.M.: La evangelización de América en las obras del padre José de Acosta, Pamplona, 1989, pág. 445.

15 Bayle: España y la educación..., pág. 358. Gimeno: El Consejo de Indias..., pág. 111. 


\begin{abstract}
"Vuestra Magestad ha mandado questos indios deprendan la lengua de Castilla. Jamás la sabrán, sino fuere cual o cual, mal sabida; porque vemos un portugués, que casi la lengua de Castilla y Portugal es toda una, está en Castilla treinta años, y nunca la sabe. ¿Pues cómo la han de saber éstos, que su lengua es tan peregrina a la nuestra, y tienen manera exquisita de hablar? A mí paréceme que Vuestra Magestad debe mandar que todos deprendan la lengua mexicana, porque no hay pueblo que no haya muchos indios que no la sepan, y la deprendan sin ningún trabajo, sino de uso y muy muchos se confiesan con ella. Es lengua elegantísima, tanto como cuantas hay en el mundo." 16
\end{abstract}

Felipe II, por cédula de 19 de septiembre de 1580, otorgaba al náhualt el merecido título de "lengua general de los indios", tanto por su difusión antes de la conquista como por la importancia que los misioneros le dieron en sus acciones. ${ }^{17}$

Sobre la preferencia por las lenguas indígenas por parte de los misioneros se ha discutido bastante. Ana Gimeno dice que esta tendencia al uso de lenguas aborígenes pudo ser debida a que muchos de los misioneros pertenecían a distintos países, pues cada orden religiosa podía mandar miembros de diversas nacionalidades, y, por tanto, era inviable la enseñanza del castellano, por desconocimiento, como la propia de cada misionero..$^{18} \mathrm{No}$ creemos que este argumento tenga demasiada validez, ya que es de suponer que la mayoría de los misioneros enviados a Indias fueron peninsulares conocedores del castellano, y en todo caso, de haber sido extranjeros, tendrían como lengua común el latín, que sí podría haberse utilizado de forma sistemática en la educación de los indios.

Se ha visto en la utilización mayoritaria de las lenguas naturales un deseo por parte de los frailes de evitar la "hispanización" del indio. A este respecto, no hemos de olvidar que los religiosos solieron tomar partido por conservar a los indígenas en sus modos peculiares de vida y cultura, evitándoles lo más posible el contacto con europeos, y consideraron la diferencia de lengua como una excelente muralla. ${ }^{19}$ De este hecho fueron conscientes los propios contemporáneos, incluso la corona, que inició - como ya se ha comentado- una campaña en favor del castellano a fin de evitar la "mexicanización" lingüística que predicaban los misioneros. Hasta se oyeron voces dentro del propio grupo religioso contra la excesiva expansión de

16 Citado por Baudot: Utopía..., pág. 105. Ricard: La conquista espiritual..., pág. 375. Bayle: España y la educación..., pág. 375.

17 Ricard: La conquista espiritual..., pág. 137.

18 Gimeno: El Consejo de Indias..., pág. 112.

19 Ricard: La conquista espiritual..., pág. 140. 
lenguas como el náhualt. La razón que se daba era la creencia de que con esta utilización de las lenguas naturales lo que se pretendía era tener sujetos a los indios y la creación de un "imperio" en el que ni la corona ni los españoles estarían incluidos..$^{20}$

Lo que es seguro es que la preferencia de los misioneros por el uso de las lenguas amerindias en la educación tuvo motivos razonadamente fundados. El primero y más esencial fue la mayor facilidad que los indios tendrían en comprender los diferentes conocimientos; en segundo lugar, porque el uso de las lenguas naturales separaba de la mente del indio el proceso educativo-evangelizador del proceso hispanizador, impuesto por unos extraños. ${ }^{21}$ Bien lo decía el padre José de Acosta:

"Vemos a los indios que cuando oyen a un predicador que les habla en su lengua nativa le siguen con grandísima atención, y se deleitan grandemente en su elocuencia, y son arrebatados por el afecto, y con la boca abierta y clavados los ojos están colgados de su palabra."22

Nuevamente la realidad mostró el poco éxito de este renovado intento. Se fue comprobando que pese al uso de la lengua indígena en la educación, los resultados eran escasos e inestables. Algunos apelaron a la pobreza de vocablos en estas lenguas para exponer ideas de carácter teológico y filosófico, lo que provocaba grandes defectos en la explicación de los misterios de la fe. ${ }^{23} \mathrm{Si}$ bien es cierta esta deficiencia de las lenguas amerindias, pronto los misioneros dieron con la solución. Por un lado, se introdujeron vocablos castellanos en las predicaciones, es decir, se "indianizaron" palabras castellanas, evitándose posibles confusiones a los indios, y, por otro lado, se recurría a perífrasis en el propio lenguaje indígena. ${ }^{24}$

En el último tercio del siglo XVI se inició una política oficial cada vez más insistente en que se enseñase en castellano; aunque en un principio no se pretendió el abandono de las lenguas aborígenes. Pero esta postura fue adquiriendo tintes más radicales, hasta el punto de que, alegando que el uso de las lenguas nativas facilitaba el recuerdo y el mantenimien-

20 Ibídem, pág. 140. Baudot: Utopía..., págs. 106-107.

21 Bayle: España y la educación..., pág. 362. Gimeno: El Consejo de Indias..., pág. 113. Ricard: La conquista espiritual..., págs. 130 y 140.

22 Citado en Paniagua Pascual: La evangelización de América..., pág. 446.

23 Gimeno: El Consejo de Indias..., pág. 115.

24 Bayle: España y la educación..., págs. 372-373. Ricard: La conquista espiritual..., págs. 144-146. 
to de las idolatrías, ${ }^{25}$ se propuso obligar a los indios a que aprendiesen el castellano y que se prohibiese el uso de sus lenguas. El rey, empero, determinó tomar una vía intermedia, y a la consulta del Consejo de Indias respondió de este modo:

"No parece conveniente apremiarles a que dejen su lengua natural, mas se puede poner maestros para los que voluntariamente quisieran aprender el castellano y se dé orden como se haga guardar lo que está mandado en no proveer los curatos sino a quien sepa la de los indios." ${ }^{26}$

La disposición del compromiso, de la convivencia del castellano con las lenguas americanas, se dio el 3 de julio de 1596:

"El Rey [...] Porque se ha entendido que en la mejor y más perfecta lengua de los indios no se puede explicar bien ni con propiedad los misterios de la fe, sino con grandes absonos e imperfecciones, y aunque están fundadas cátedras donde serán enseñados los sacerdotes que hubieren de adoctrinar a los indios, no es remedio bastante, por ser grande la variedad de las lenguas, y que lo sería introducir la castellana, como la más común y capaz; os mando que con la mejor orden que se pudiere y que a los indios sea de menos molestia y sin costa suya, hagáis poner maestros para los que voluntariamente quisieran aprender la lengua castellana, que esto parece podrían hacer bien los sacristanes, así como en estos reinos en las aldeas enseñan a leer y escribir y la doctrina. Y asimismo ternéis muy particular cuidado de procurar se guarde lo que está mandado cerca de que no se provean los curatos, si no fuere en personas que sepan muy bien la lengua de los indios que habían de enseñar, que ésta, como cosa de tanta obligación y escrúpulo, es la que principalmente os encargo, por que toca a la buena instrucción y cristiandad de los indios [...]"27

La preocupación de la corona por esta "cosa de tanta obligación" queda de manifiesto con un mero repaso a la Recopilación de las Leyes de Indias. ${ }^{28}$ La realidad fue que, con el paso del tiempo, el castellano se extendió cada vez más; pero no sería hasta el siglo XVIII cuando se convirtiera en una asignatura "obligatoria" en todas las escuelas. ${ }^{29}$

25 Consulta del Consejo de Indias a S.M., Madrid, 20 de junio de 1596. Archivo General de Indias (en adelante AGI), Indiferente General, 744, 1, 8.

26 Real decreto de Felipe II a la consulta del Consejo de Indias de 20 de junio de 1596, ibídem.

27 Real cédula de Felipe II al Conde de Monterrey, virrey de Nueva España, Madrid, 3 de julio de 1596. AGI, Indiferente General, 427, 30, 458r.- 458v.

28 Recopilación de las Leyes de Indias (1680), Madrid, 1973, Libro I, Título XVIII, Ley 4; Libro I, Título XV, Ley 5 y 6.

29 Borges: Historia de la Iglesia..., pág. 516. 


\section{El sistema de enseñanza}

Nada más iniciarse la colonización en las Indias se puso en práctica un sistema de enseñanza que, debido a la claridad de ideas que presentó, no podemos pensar que fue improvisado ni desarrollado sobre la marcha. ${ }^{30}$ Ricard opina que en "una sociedad de lo que se ha convenido llamar tipo teocrático - como la española o la azteca— la enseñanza nunca puede hallarse separada de la educación. Por consiguiente, la enseñanza de la doctrina cristiana y la de la lectura y la escritura van paralelas, se hallan intimamente ligadas y son dadas a menudo por los mismos maestros." ${ }_{31}$

Era lógico, por consiguiente, que los misioneros pensaran en utilizar las escuelas para enseñar el catecismo - sobre todo al principio- $\mathrm{y}$, simultáneamente, las primeras letras, pues estaban acostumbrados a ver cómo la lectura y la escritura se aprendían en cartillas de la doctrina cristiana. De este hecho, asociación entre enseñanza y catequesis, surgieron las dos primeras características del sistema escolar indiano: una orientación de los centros educativos hacia la formación religiosa más fuerte que en la Península y la iniciativa exclusiva de la Iglesia en la impartición de la enseñanza. ${ }^{32}$ De la tradición indígena se tomaron la idea de los internados al lado de los conventos y el recogimiento de las niñas. ${ }^{33}$

\section{Tipos de centros educativos}

Para la educación e instrucción del indio se recurrió al empleo de siete clases de centros de formación y sus respectivos sistemas: internados femeninos, centros interraciales, centros interclasistas, colegios de enseñanza "media", educación de niños en España, escuelas elementales y colegios de niños nobles. ${ }^{34}$ De todos éstos, sólo los dos últimos llegaron a con-

30 Sobre los antecedentes peninsulares de la política educativa véase Kobayashi, José María: La educación como conquista, México, 1974, págs. 131-145; Sánchez Herrero, José: “Alfabetización y catequesis en España y América" en Teología y Evangelización (actas), Pamplona, 1990, págs. 237-258; Luque Alcaide, Elisa: "La evangelización y la educación: Colegios y Universidades" en Historia de la Evangelización en América (actas), Ciudad del Vaticano, 1992, pág. 535.

31 Ricard: La conquista espiritual..., pág. 376.

32 Laspalas Pérez, Francisco José: "Una visión de la obra educativa de España en América (siglo XVI)” en Teología y Evangelización (actas), Pamplona, 1990, págs. 140-141.

33 Pazos, M.R.: "Los franciscanos y la educación literaria de los indios mexicanos" en Archivo Ibero-Americano, núm. 49, año XIII (1953), pág. 29. Véase también Kobayashi: La educación..., págs. 66-73 y 103-106. 
figurar una unidad espacio-temporal; el resto apareció siempre de forma puntual, sin la sistematización de las escuelas elementales y los colegios de niños nobles.

Los internados femeninos tuvieron un escaso desarrollo debido a que la mentalidad de la época apenas cuidaba la instrucción de las niñas. Abundaron más las denominadas "escuelas de amiga", de régimen externo, en las que las alumnas aprendían algunos rudimentos de la doctrina cristiana, labores domésticas (cosido y bordado) y donde con relativa frecuencia ejercitaban la lectura; sin embargo, rara vez se aprendía a escribir. ${ }^{35}$

Los centros interraciales estaban integrados por alumnos indios, esencialmente hijos de caciques, y españoles; pero a veces también aceptaban negros y mestizos. Pudieron tener tanto carácter de internado como de régimen externo; los había de enseñanza elemental (lectura, escritura, canto y catecismo), como pudieron ser el Colegio del Nombre de Jesús a cargo de los agustinos hacia 1537, o el jesuita de San Juan de Oaxaca fundado en 1575; y de enseñanza superior (gramática, arte, teología), como el que establecieron los agustinos en 1541 en Michoacán, el Colegio de Tiripitío.

Los centros interclasistas fueron, en esencia, producto de la orden jesuítica. Se trataban de una modalidad intermedia entre las escuelas elementales y los colegios de niños nobles. Tenían un carácter selectivo y de internado, pero sus alumnos, siempre indios, no tenían por qué pertenecer a la nobleza local. Dos ejemplos de este tipo de centros fueron el llamado Seminario de Tepotztlán, de 1582, y el de San Gregorio, de 1586, donde se enseñaba castellano, lectura, escritura, catecismo, música y oficios como la platería, la pintura o la escultura.

Los colegios de enseñanza "media" se limitaron a los fundados por los franciscanos en Tlatelolco y Quito. Normalmente se han denominado a estos centros colegios de enseñanza superior -incluso en el siglo XVI-; pero Pedro Borges cree que el término adecuado es el de "media", pues suponían un nivel superior al elemental, aunque no alcanzaban el universitario. Estos colegios estaban destinados exclusivamente a los niños nobles. La enseñanza se compuso, en principio, de lectura, escritura y gramática (latín), pero con el tiempo se fue ampliando a la retórica, la astrología, el

34 Clasificación tomada de Borges: Misión y civilización..., pág. 227; y Luque Alcaide: "La evangelización y la educación...”, págs. 536-538.

35 Gonzalbo Aizpuru, Pilar: Las mujeres en la Nueva España. Educación y vida cotidiana, México, 1987, especialmente págs. 127-147. 
castellano e incluso la medicina ${ }^{36} \mathrm{La}$ aparición de esta clase de colegios dio lugar a mucha polémica, de la que hablaremos más adelante.

El envío de niños indios a España para estudiar fue iniciado ya en 1493 por Cristóbal Colón, y constituyó una práctica más o menos generalizada durante varias décadas del siglo XVI. ${ }^{37}$ No debemos confundir a los indios que por iniciativa propia o por la de sus encomenderos vinieron a España con los expresamente enviados con el objeto de estudiar en conventos españoles. La entrada de los primeros fue prohibida a partir de 1526; el segundo grupo lo integraban niños nobles. El sistema se fue restringiendo con el tiempo, pues resultaba más caro, peligroso e incómodo que poner a los niños a estudiar en los colegios que ya florecían en América. No obstante, debe considerarse esta iniciativa como una prueba del interés que, desde el inicio de la colonización, se puso en la formación de la elite indígena; eso sí, no por mero altruismo, sino como medio de instruir al resto de indios y por la conveniencia de que las autoridades locales fuesen conocedoras de la lengua castellana y de la escritura, a fin de servir de nexo entre los colonizadores españoles y la gran masa indígena. ${ }^{38}$

Las escuelas elementales y los colegios de niños nobles fueron los únicos que se difundieron por todo el Nuevo Mundo. Las diferencias teóricas entre unos y otros estaban muy claras. Las escuelas elementales tenían régimen externo y sus alumnos pertenecían bien sólo al pueblo, si en el lugar no había nobleza o ésta iba a sus propios colegios, bien a ambos grupos si no existían estas condiciones. Los colegios de niños nobles poseían un régimen de internado y se destinaban exclusivamente a los hijos de caciques. El nivel de enseñanza era el mismo: se reducía a la lectura, la escritura, la música, el catecismo y, a veces, el latín. Pero si en teoría eran fácilmente distinguibles, esto no ocurría en la práctica, al menos en los primeros tiempos.

Parece más lógico que se constituyesen primero los colegios de niños nobles, pues desde el primer momento se vio en la educación de estos niños uno de los mejores instrumentos para influir en la sociedad indígena, ya

36 Borges: Misión y civilización..., pág. 282.

37 En abril de 1531, se enviaba una real cédula a Francisco Tello, tesorero de la Casa de la Contratación, para que informase sobre la educación que estaban recibiendo tres niños indios en el monasterio de Santa María de las Dueñas. (Colección de documentos inéditos relativos al descubrimiento, conquista y organización de las antiguas posesiones españolas en América y Oceanía (en adelante CDI), de Pacheco, Cárdenas y Torres Mendoza, Madrid, 1864-1884, volumen XLII, págs. 462-463).

38 Sobre el papel de las elites indígenas como nexo entre los conquistadores y el pueblo aborigen, véase Stern, J. Steve: Los pueblos indígenas del Perú y el desafío de la conquista española. Huamanga hasta 1640, Madrid, 1986. 
que en un futuro serían sus dirigentes, y en el presente influirían en su padres, que eran seguidos "ciegamente" por sus subordinados. ${ }^{39}$

Muy pronto, sin embargo, estos primeros colegios de niños nobles también incluyeron a niños del pueblo, como nos lo indica fray Jerónimo de Mendieta:

"[...] aunque en algunas partes hubo descuido de hacer esta diferencia (especialmente en los niños del pueblo pequeños donde es poca la gente), que sin distinción se enseñan a todos los niños, hijos de principales y de plebeyos, a leer y escribir en las escuelas." ${ }^{40}$

De igual manera, en los inicios todos los colegios eran internados, pero luego muchos dejaron paso a un régimen externo, según nos cuenta fray Bernardino de Sahagún:

"A los principios, como hallamos que en la república antigua criaban los muchachos y muchachas en los templos [...] tomamos aquel estilo de criar los muchachos en nuestras casas, y dormían en la casa que para ellos estaba edificada junto a la nuestra [...] Pero como no se ejercitaban en los trabajos corporales como solían [...] porque ejercitábamos con ellos la blandura y piedad que entre nosotros se usa, comenzaron a tener bríos sensuales [...] y así los echamos de nuestras casas para que se fuesen a dormir a casa de sus padres; y venían a la mañana a las escuelas a aprender, y esto es lo que ahora se usa." 41

Al poco tiempo, pues, de iniciarse estos tipos de centros de enseñan$\mathrm{za}$, se establecieron ya totalmente las diferencias, dando lugar a las dos modalidades descritas.

\section{Alumnos y profesores}

En la enseñanza e instrucción de los indígenas se excluyó a los adultos de una forma sistemática, por la dificultad que su educación planteaba, la poca utilidad inmediata y la resistencia a una actividad mental poco habitual para ellos. Fueron los niños y jóvenes indios los objetos de esta enseñanza, pues además de una mayor facilidad, se conseguía la aculturación de los que en un futuro inmediato serían los adultos de la sociedad

39 Borges: Misión y civilización..., pág. 264. Laspalas Pérez: "Una visión de la obra...”, pág. 143. Pazos: "Los franciscanos...", pág. 5.

40 Mendieta: Historia Eclesiástica..., Libro IV, Capítulo XVI, pág. 43.

41 Sahagún, fray Bernardino de: Historia general de las cosas de la Nueva España, Madrid, 1990, Libro X, Capítulo XXVII, págs. 721-722. 
indígena, y, mientras tanto, eran magníficos elementos introductores de la nueva cultura - y religión - en sus casas y familias. ${ }^{42}$

En la América del siglo XVI - y casi siempre-, se dio preferencia a la enseñanza de los niños, mientras que las escuelas elementales — las más difundidas - de niñas fueron escasas, cuando no inexistentes. Dentro del grupo masculino tuvieron prioridad los hijos de la nobleza local, como puede comprobarse por la aparición de colegios especiales para ellos (colegios de niños nobles), sistemas educativos no al alcance de otros (envío de niños a España o los colegios de enseñanza "media"), y cuando la escuela no podía satisfacer la enseñanza de toda la infancia de un lugar se procedía a una selección en la que nunca faltaban los niños nobles. Esta selección, de acuerdo con un criterio estamental, ha dado lugar, a posteriori, a duras críticas contra los misioneros. Empero, si nos colocásemos en el lugar de un hombre del siglo XVI, no existía nada de extraño. No olvidemos que los misioneros, como hombres de su tiempo, estaban inmersos en el ideal de la sociedad estamental, en la que cada estamento tenía unas funciones y unos privilegios, o no, determinados; se trataba, en definitiva, de un "concepto feudal" de la enseñanza. ${ }^{43} \mathrm{Si}$ nos situásemos en el lado indígena, tampoco les causaba asombro, pues en los tiempos prehispánicos también se hacía distinción entre la nobleza y la plebe. ${ }^{44}$ De todas formas, como hemos visto, el sistema no fue tan rígido y cerrado.

En las escuelas elementales el número de alumnos no siguió una regla fija. Osciló entre treinta y sesenta, cuando menos, y ochocientos y novecientos, cuando más, según la extensión y población del lugar. En el resto de centros la cifra media rondaba el centenar.

La costumbre más generalizada consistía en que fueran los propios misioneros, y entre ellos los religiosos no sacerdotes, quienes se encargaran de la formación de los indios. No obstante, también hubo maestros que no tenían por qué ser religiosos. En el colegio de niños nobles de Santo Domingo aparecía un bachiller dando clases de gramática; los maestros de las escuelas elementales de Jalisco eran todos indios, etc.

42 Medina, M.A.: "Métodos y medios de evangelización de los dominicos en la Nueva España” en Los Dominicos y el Nuevo Mundo (actas), Madrid, 1988, pág. 166.

43 Kobayashi: La educación..., págs. 263-266. En 1625, la orden jesuita se expresaba de esta manera: “(...) si interesa mucho el estudio a la gente común, mucho más importa que no les falte a los hijos de los príncipes y gentes nobles, porque es la parte más principal de la República, la cual, con sus buenas o malas costumbres, llevan tras sí todo lo demás, y porque con el tiempo viene a parar en sus manos el gobierno y administración de Reino." (Citado por Domínguez Ortiz, Antonio: Las clases privilegiadas del Antiguo Régimen, Madrid, 1985, pág. 407.)

44 Kobayashi: La educación..., págs. 66-73. 


\section{Contenido y metodología de la enseñanza}

En las escuelas elementales, pero también en otros tipos de centros con el mismo nivel de enseñanza, los contenidos abarcaron siempre el catecismo, la lectura y la escritura en lengua indígena, y la música. La enseñanza del latín estuvo más generalizada de lo que parece, sobre todo por el intento de preparar a los niños indios para el sacerdocio o para que, al menos, colaborasen con los misioneros. También en muchos centros se concedió una especial importancia a la caligrafía, arte en el que los indios mostrarían ser verdaderos maestros. La enseñanza del castellano no se generalizó hasta el siglo XVIII; antes no se siguió una regla y, normalmente, estuvo al arbitrio de los misioneros. ${ }^{45}$

Evidentemente las escuelas necesitaban textos para la enseñanza, que fueron distintos según el tipo de centro y su contenido académico. En los comienzos, y con el propósito de que los indios aprendiesen el castellano, los religiosos utilizaron los métodos de enseñanza europeos: cartillas, catones, carteles con el alfabeto y la formación de sílabas... Luego se inició la confección de textos en lenguas amerindias. ${ }^{46}$

El envío de cartillas y catones desde la Península al Nuevo Mundo se hizo en grandes cantidades, sin perder de vista las que se hicieron en la propia América. Ya en fecha tan temprana como 1505 se registraba en la nao Santa María del Antigua ciento treinta y ocho cartillas "para leer moços". ${ }^{47}$ En 1512, la Casa de la Contratación encargó al famoso impresor Jácome Cromberger dos mil cartillas a dos maravedís para entregarlas a fray Alonso de Espinar, que iba a la Española. ${ }^{48}$ En 1585, en la armada que iba a Tierra Firme, la nao Santa Catalina llevaba unas cajas de libros destinadas a Alonso Ruiz y que contenían dos mil quinientas cartillas, mil doscientos catones, veinte artes de cuentas, etc. ${ }^{49}$ Ejemplos como éstos abundan en el Archivo General de Indias.

45 Ibídem, pág. 252. Luque Alcaide: "La evangelización y la educación...”, pág. 539. Borges: Misión y civilización..., págs. 232-233. Borges: Historia de la Iglesia..., pág. 724.

46 Hernández Aparicio, Pilar: "Catecismos, sermonarios... de los dominicos en las bibliotecas españolas” en Los Dominicos y el Nuevo Mundo (actas), Madrid, 1988, pág. 335.

47 Gil Fernández, Juan: "El libro greco-latino y su influjo en Indias", Libro Homenaje a Enrique Segura Covarsi, Bernardo Muñoz Sánchez y Ricardo Puente Broncero, Badajoz, 1986, pág. 65.

48 Real cédula a los oficiales de la isla Española, Burgos, 28 de julio de 1512. AGI, Indiferente General, 418, 3, 329r.-329v.

49 Torre Revello, José: "Las cartillas para enseñar a leer a los niños en la América española" en Thesaurus (Boletín del Instituto Caro y Cuervo de Bogotá), XV (1960), págs. 218. 
En general, puede decirse que hubo tres clases de textos de alfabetización en América. ${ }^{50}$ La primera consistió en las cartillas, abecedarios o catones en castellano, dirigidos en principio a los niños españoles, pero que servían también para niños indios a falta de otro texto más apropiado, cuando se enseñaba el castellano en la escuela o cuando los niños indios estaban relativamente hispanizados. La segunda clase eran las cartillas o abecedarios expresamente elaborados por los mismos misioneros para los niños indios, y en el material que tuviesen, ya que uno de los mayores problemas a la hora de la obtención de material escolar fue la falta de papel, que tuvo que ser suplantada incluso con tablillas de madera. La tercera y última clase de textos fueron los denominados catecismos o doctrinas alfabetizantes, que consistían en exposiciones breves (catecismos) o extensas (doctrinas) del cristianismo, pero que servían a la vez para aprender a leer y con los que podía lograrse tanto la evangelización como la alfabetización del indio. ${ }^{51}$ Estos textos comenzaban con las letras del alfabeto, con sus variantes, así como algunos signos de abreviación; luego las vocales, solas y combinadas con letras consonantes; seguía, como ejercicio de lectura y como contenido que había que asimilar, el texto propio de cada caso. Los catecismos presentaban una serie de textos a aprender de memoria: padre nuestro, avemaría, credo, salve, artículos de la fe, mandamientos de Dios y de la Iglesia, sacramentos... Las doctrinas añadían, además, una explicación de los puntos más importantes del cristianismo. ${ }^{52}$

Una vez que se aprendía el abecedario, y a falta de otro libro de lectura, se procedía al aprendizaje de estos catecismos o doctrinas, cuya elaboración solía ser una de las primeras tareas de los misioneros, y constituyeron el grueso de los ejemplares impresos en las primeras imprentas del Nuevo Mundo. Estos textos podían encontrarse en castellano, latín, una lengua indígena o una combinación de las tres lenguas, como por ejemplo la Cartilla para aprender a leer, atribuida a fray Pedro de Gante, que se imprimió en 1569 , y que estaba en castellano, latín y náhualt. ${ }^{53}$ La activi-

50 Borges: Misión y civilización..., pág. 237.

51 Luque Alcaide, Elisa: "Los instrumentos pastorales del III Concilio mexicano (1585)" en Scriptia Theológica (Pamplona), vol. XXIII, fascículo I (1991), págs. 185-196. Hernández Aparicio: "Catecismos, sermonarios...", pág. 255.

52 Durán, J. Guillermo: "La transmisión de la fe. 'Misión Apostólica', catequesis y catecismos en el Nuevo Mundo (siglo XVI)" en Historia de la Evangelización en América (actas), Ciudad del Vaticano, 1992, págs. 300-303.

53 Véase Valton, Emilio: Una cartilla para enseñar a leer, México, 1977. 
dad de los misioneros en este terreno fue tal, que rara era la lengua que no tenía su texto. ${ }^{54}$

El momento decisivo llegaba a la hora de ponerse a enseñar el alfabeto a los indios. En sí misma, su enseñanza no resultó muy costosa. Diego de Valadés nos ofrece un testimonio de su participación en la alfabetización de Nueva España: "si la escritura se componía de imágenes y sonidos, es conveniente reducir asimismo la ciencia de las letras a sonidos e imágenes". ${ }^{55}$ Para ello se aprovechó la casual semejanza de algunos objetos a las letras (la A parece un compás o una escalera, la B una mandolina, la $\mathrm{C}$ una herradura, la E una sierra, la I una columna...) para, de este modo, dar un cierto contenido a las letras, de forma que no resultasen tan abstractas. ${ }^{56}$ Es cierto que muchos objetos no tenían nada que ver con las letras; en este caso, se les daba un significado convencional, como en los jeroglíficos indígenas. Éste ha sido llamado por Ricard "método ideográfico". ${ }^{57}$ Por otra parte, las letras podían asociarse a sonidos (la A podía sugerir Antonio, la B el de Bartolomé...): Ricard lo denomina "método fonético". ${ }^{58}$

Más complicado resultó adaptar el alfabeto latino a las lenguas amerindias, ya que los signos resultaban "una vestidura demasiado ancha para las lenguas americanas, en las que sobraban letras, claro que a veces faltaban, o, lo que era más frecuente, sobraban y faltaban a la vez." ${ }^{59}$

La dificultad dependía en gran medida de la lengua amerindia de que se tratase. Para algunas, cuyo sistema fonético era bastante sencillo, el trabajo no era insuperable. En ese caso, los misioneros lograron su objetivo con relativa facilidad. Así, los fonemas propios del náhualt son unos veinte, y el alfabeto latino es, en general, suficiente para representarlos. Algunos sonidos delicados se pudieron representar por conjuntos de consonantes como "tz" o "tl" y, en total, los misioneros utilizaron diecisiete letras de nuestro alfabeto. Todavía hoy el náhualt se escribe según las normas establecidas en el siglo XVI, salvo algunos detalles técnicos.

Para el maya, la reducción fonética a través del alfabeto latino resultó más problemática; con todo, también aquí y de forma general, se lograron

54 Una lista de autores de las obras catequética (cartillas, doctrinas, gramáticas, etc.) residentes en América en Sánchez Herrero: "Alfabetización y catequesis...”, págs. 259-263.

55 Citado en Esteve Barba, Francisco: "Cómo empezó América a leer" en Boletín de la Dirección General de Archivos y Bibliotecas, Madrid, 1952, pág. 10.

56 Alejos, Carmen José: Diego Valadés, educador de Nueva España. Ideas pedagógicas de la Rethórica Cristiana (1579), Pamplona, 1994, pág. 151.

57 Ricard: La conquista espiritual..., pág. 379.

58 Ibídem, pág. 379.

59 Esteve Barba: "Cómo empezó América...”, pág. 9. 
los objetivos que los misioneros buscaban. Igualmente, los problemas del quechua fueron solucionados de forma conveniente. Esto no ocurría con otras lenguas; el otomí, por ejemplo, con sus cuarenta y ocho sonidos, planteó dificultades insalvables para los medios que poseían los misioneros, y tuvieron que conformarse con ligerísimas aproximaciones. ${ }^{60}$

Los intentos fueron más allá de la pura transcripción fonética de las lenguas indígenas; se necesitaba el conocimiento de los distintos elementos de las lenguas, su ordenación, sus funciones, etc., es decir, se requería la confección de gramáticas y vocabularios, que no tardaron en surgir. La gramática náhualt de fray Andrés del Olmo estaba lista en 1547, y la primera edición del diccionario náhualt de fray Alonso de Molina data de 1550; el Arte i doctrina christiana en lengua otomí de fray Alonso Rongel es anterior a 1548; la gramática de tarasco de fray Maturino Ghiberti está fechada en 1558 y su diccionario de la misma lengua en 1559. Dentro del siglo XVI, se pueden encontrar el Arte de la lengua Zapoteca de fray Pedro de Feria, ${ }^{61}$ la Gramática y arte de la lengua general de Perú y El Lexicón o Vocabulario de la lengua general del Perú de fray Domingo de Santo Tomás, de $1560,{ }^{62} \mathrm{y}$ un largo etcétera. A estas gramáticas y vocabularios se unían los catecismos y doctrinas cristianas para la educación de los indios, muchas de las cuales estaban en lenguas indígenas o bilingües; así, de 1539 es la Breve y más compendiosa doctrina cristiana en lengua mejicana y castellana, ${ }^{63} \mathrm{o}$, en el Perú, la Doctrina cristiana en quechua y aymara, de $1584 .{ }^{64}$

\section{La difusión de la enseñanza por el siglo XVI indiano}

Nos centraremos sólo en el proceso de puesta en marcha y difusión por las Indias de las escuelas elementales y colegios de niños nobles, pues, como se expuso en páginas anteriores, fueron los únicos centros que se organizaron de forma sistemática por todo el continente.

60 Baudot, George: Las letras precolombinas, México, 1979, págs. 33-34.

61 Para todo lo anterior, véase García Icazbalceta, Joaquín: Bibliografía mexicana del siglo XVI, México, 1954 (edición original de1886), passim.

62 A principios de 1560 salía de la imprenta de Francisco Fernández de Córdoba, impresor de Valladolid, los 1582 ejemplares del Lexicón, para que se entregasen a fray Domingo de Santo Tomás. (Real cédula de Felipe II a Francisco Fernández de Córdoba, Madrid, 29 de marzo de 1560. AGI, Indiferente General, 425, 23, 467r.)

63 Griffin, Clive: Los Cromberger. La historia de una imprenta del siglo XVI en Sevilla y Méjico, Madrid, 1991, pág. 124.

64 Ibídem, pág. 35. Hernández Aparicio: “Catecismos, sermonarios...”, págs. 338-343. 
La política de creación de escuelas para indígenas empezó muy pronto. Ya en 1503, en las instrucciónes que los Reyes Católicos dieron al primer gobernador de La Española, Nicolás de Ovando, se le ordenaba:

"que luego haga hacer en cada una de las dichas poblaciones y junto con las dichas iglesias una casa en que todos los niños que hubiere en cada una de las dichas poblaciones se junten cada día dos veces para que allí el dicho capellán les muestre leer y escribir, y santiguar y signar y la confesión, el Paternoster, el Avemaría, el Credo, el Salve Regina." ${ }^{5}$

Las leyes de Burgos, en 1512, establecían que todos los hijos de caciques menores de trece años fuesen recogidos por los franciscanos para enseñarlos en la lectura, la escritura y la doctrina durante un período de cuatro años, para que luego volviesen a casa de sus padres. ${ }^{66} \mathrm{~A}$ fines de febrero de 1513, el clérigo Hernando Suárez recibió el nombramiento de maestro de Gramática, para que crease en Santo Domingo una escuela a la que debían de acudir los hijos de los indios principales para aprender a leer y escribir en latín. ${ }^{67}$

Desde La Española, franciscanos y dominicos realizaron un ensayo de "conquista pacífica", que tuvo por escenario la costa oriental de Venezuela; queda constancia de que al menos los franciscanos utilizaron allí internados para niños indígenas en $1519 .{ }^{68}$

En 1523 llegaron a México los primeros misioneros propiamente dichos, ya que los anteriores fueron sólo capellanes de los conquistadores. Ese mismo año, fray Pedro de Gante fundaba la primera escuela de Nueva España en Texcoco, junto al palacio del por entonces señor de la ciudad, Itxtlixoxhilt; ${ }^{69}$ fue fray Pedro de Gante "el primero que en esta Nueva España enseñó a leer, escribir y cantar y la doctrina cristiana". ${ }^{70}$ La siguiente escuela se situó en Ciudad de México y fue fundada por el segundo grupo de misioneros franciscanos que llegaron a Nueva España, los llamados "doce apóstoles", en 1524. Luego siguieron la escuela de Huetjotzingo

65 Konetzke: Colección de documentos..., Tomo II, pág. 11.

66 Muro Orejón, Antonio: "Ordenanzas reales sobre indios: Leyes de Burgos de 1512" en Anuario de Estudios Americanos, Sevilla, vol. XIII (1956), págs. 64-85.

67 Gil Fernández, Juan: "El libro greco-latino...", págs. 73-74 y 76.

68 Gómez Canedo, Lino: La educación de los marginados en la época colonial, México, 1982, págs. $10-12$.

69 Trueba, Alfonso: Fray Pedro de Gante, México, 1959, págs. 18-19.

70 Mendieta: Historia Eclesiástica..., Libro V, Capítulo XVIII, págs, 154-155; Torquemada: Monarquía..., Libro XX, Capítulo XIX, pág. 184. 
en 1525 y, en 1527, la de Tlaxcala y la de San José de los Naturales en la capital. Estas escuelas constituirían la base del sistema educativo franciscano en México, sistema que copiarían otras órdenes y que pasó al resto del continente en años posteriores..$^{71}$ En 1569 los franciscanos tenían en Nueva España unos sesenta y nueve conventos-escuelas; en la relación presentada por esta orden al visitador Ovando en ese año, afirmaban que en la provincia de Michoacán existían catorce centros en los que un maestro indígena enseñaba a los niños a leer, escribir y cantar. ${ }^{72}$

Es más que probable que el modelo mexicano se implantase en Guatemala y toda la región centroamericana, pues gran parte de sus primeros misioneros procedían de Nueva España o mantenían estrecho contacto con ella. En Guatemala, las escuelas de alfabetización comenzaron a funcionar en 1536, y fueron obra de la orden mercedaria, a la que pronto se unieron franciscanos y dominicos. Fray Juan de Mansilla estableció tres escuelas (Santiago de Guatemala, Atitlán y Tecpanatitlán) a fin de que "se junten los hijos de los principales y los demás que vuieren de aprender", para lo que nombró a "preceptores frailes que saben la lengua de los yndios, para que les enseñen la lengua de España y a leer [...]"73 En Nicaragua, consta que en 1565 el mercedario Nicolás del Valle mantenía escuelas públicas en los pueblos que administraba. Se hizo célebre en Yucatán fray Juan de Herrera, que fundó escuelas en Maní durante varios años, de donde salieron "excelentes discípulos, lectores, escribanos y cantores." $" 14$

Al igual que en México, los misioneros del Perú tuvieron por costumbre fundar una escuela de primeras letras en cada convento. Las primeras instrucciones para la construcción de escuelas datan de 1535, pero no fue hasta 1541 cuando se constituyeron de verdad. Hubo religiosos, como Tomás de San Martín y Domingo de Santo Tomás, que llegaron a fundar sesenta escuelas cada uno entre 1550 y $1560 .{ }^{75}$

En la actual Colombia, fue el protector de indios de Santa Marta el iniciador de las escuelas para indios en 1530; aunque no sería hasta 1538 cuando se iniciara una política educativa más seria. Destacó, dentro del

71 Pazos: "Los franciscanos...”, págs. 13-19.

72 Códice franciscano, México, 1941, pág. 153.

73 Ibidem, pág. 187. López, Anastasio: "Los primeros franciscanos en Guatemala" en Archivo Ibero-Americano, año XVII, núm. 99 (1930), pág. 427.

74 Mendieta: Historia Eclesiástica, Libro IV, Capítulo VI, pág. 22.

75 Vargas-Ugarte, Rubén: Historia de la Iglesia en el Perú, Lima, 1953, vol. I, pág. 328. Armas Medina, Fernando de: Cristianización del Perú (1532-1600), Sevilla, 1953, pág. 390. 
convento franciscano de Santa Fe de Bogotá, fray Pedro de Vallejo, que durante doce años se ocupó de enseñar a leer y escribir a muchos indios. ${ }^{76}$

En Ecuador, existen documentos que hablan de la existencia de colegios de niños nobles; en 1552, fray Jodoco Ricke fundó una escuela que algunos años más tarde sería ampliada por fray Francisco de Morales, convirtiéndola en "un Colegio al modo y orden del de Nueva España" donde se enseñaría, además de las primeras letras, diversos oficios, gramática y castellano. ${ }^{77}$

En el resto de las Indias también llegó la alfabetización, pero ya en el siglo XVII, con el establecimiento de las misiones jesuíticas en el Paraguay, Uruguay, Argentina y parte de Chile.

\section{La alfabetización indígena: una cuestión polémica}

Como hemos señalado, la instrucción de los indios se inició desde el principio de la colonización española en el Nuevo Mundo. El trabajo de los misioneros fue tan intenso que hacia 1559 había en América unas doscientas escuelas donde se enseñaba a leer, escribir, cantar y la doctrina cristiana. Los indios respondieron brillantemente en sus capacidades de captar conocimientos y aplicación de éstos; los testimonios son numerosos. Fray Toribio de Benavente, "Motolinía", nos da una exquisita muestra de la suficiencia e ingenio que observó en los indios:

"El que enseña al hombre la ciencia, ese mismo proveyó y dio a estos indios naturales grande ingenio y habilidad para aprender todas las ciencias, artes y oficios que les han enseñado, porque con todos han salido en tan breve tiempo, que en viendo los oficios que en Castilla están muchos años en deprender, acá con sólo mirarlos y verlos hacer han mucho quedado maestros. Tienen el entendimiento vivo, recogido, sosegado $[\ldots]]^{\prime 78}$

Mendieta, que compartía la opinión de "Motolinía", se percataba de que las perspectivas de éxito en la formación indígena se frustraban cuando los niños crecían. Tanto en los niños criollos como en los indios com-

\footnotetext{
76 López, Anastasio: "Los franciscanos en Colombia y Venezuela" en Archivo Ibero-Americano, año VIII, núm. 43 (1921), pág. 92.

77 Armas Medina: Cristianización..., págs. 390-391.

78 Benavente, fray Toribio de: Historia de los indios de la Nueva España, Madrid, 1988, Tratado II, Capítulo XII, pág. 270.
} 
probaba "que los más agudos y vivos parecen ser en general los nacidos en estas tierras que los nacidos en nuestra España, puesto que después creciendo suelen perder esta viveza." 79

A pesar de esta observación de Mendieta, la educación iba funcionando, y no surgían recelos en la población española por esta instrucción elemental a los indios, que pronto se amplió a una serie de trabajos mecánicos y artesanales. El padre Acosta defendió en 1589 la necesidad de fundar escuelas elementales, porque veía en la educación de la infancia y la juventud un medio para que los nativos se convirtieran en verdaderos hombres. ${ }^{80}$ Sin embargo, existieron personas que se mostraron en contra de la educación de los indios. Juan Peláz afirmaba en 1530 que sólo era necesario que el indio supiese el padre nuestro y el avemaría; el escribano Jerónimo López opinaba que era bueno que supiesen la doctrina, pero era perjudicial que entendieran de la lectura y la escritura. ${ }^{81}$

La verdadera polémica saltó cuando se pensó en dar a los indios una instrucción superior a la que se impartía en las escuelas elementales, que les permitiera salir de su inferioridad y asumir funciones directoras en la nueva sociedad colonial. Fray Juan de Zumárraga, primer arzobispo de Nueva España, y el virrey don Antonio de Mendoza pensaron un proyecto para abrir la cultura a los indios y que, de acuerdo con sus habilidades, pudieran acceder a puestos de responsabilidad.

Realmente, la idea de dar una instrucción superior a los indios ya aparecía en una carta del contador Rodrigo de Albornoz en 1525:

"Para que los hijos de los caciques y señores, muy poderoso Señor, se instruyan en la fe, hay necesidad nos mande Vuestra Magestad se haga un colegio donde les muestre leer y gramática y filosofía y otras artes, para que vengan a ser sacerdote [...]" ${ }^{\prime 2}$

El proyecto de Mendoza, Zumárraga y el presidente de la Audiencia, Fuenleal, se hizo realidad en 1536, cuando se fundó, el 6 de enero, el Colegio de la Santa Cruz de Santiago de Tlatelolco. ${ }^{83}$ Los franciscanos vieron en él la culminación a su obra evangelizadora. Se trataba de una institución a la que sólo accedían jóvenes indios nobles en régimen de internado. Tradicionalmente, se ha pensado que la finalidad del colegio fue la

79 Mendieta: Historia Eclesiástica..., Libro II, Capítulo XXVII, pág. 148.

80 Paniagua Pascual: La evangelización de América..., pág. 458.

81 Borges: Misión y civilización..., pág. 234.

82 Citado en Gómez Canedo: La educación de los marginados..., pág. XVII.

83 Carta de don Antonio de Mendoza, virrey de Nueva España, al rey, de 10 de diciembre de 1537. CDI, vol. II, pág. 204. 
formación de sarcerdotes. No hay duda de que éste parece que constituyó uno de los fines; pero no el único ni el más importante. Inicialmente, el objetivo era la enseñanza del latín y los autores clásicos (Gramática), historia, retórica, oratoria, filosofía, astronomía, teología y medicina: constituía, en definitiva, la puerta de acceso a la Universidad ${ }^{84}$ La enseñanza solía durar tres años, y entre los profesores hubo verdaderos maestros que aún hoy día conservan su prestigio, tal fue el caso de Focher o fray Bernardino de Sahagún.

En 1546 el colegio sería abandonado en su dirección por los franciscanos, debido a la falta de medios económicos, y fue entregado a la corona, haciéndose cargo del colegio los propios indios que habían sido formados allí. En 1570, prácticamente en ruinas y con el número de alumnos muy debilitado por las epidemias, volvió a manos franciscanas; pero ya no tuvo el esplendor de antes. ${ }^{85}$

La fundación del Colegio de Tlatelolco puso de manifiesto las diferentes posturas de las órdenes religiosas con respecto a la instrucción del indio. Los franciscanos fueron siempre los que mantuvieron una mayor apertura de ideas; preferían las escuelas elementales a los colegios de niños nobles y, como se ha visto, no tenían reparo en ofrecer una enseñanza superior al indio. Los agustinos no hacían distinción entre indios nobles y plebeyos; pero su mayor atención estuvo en la enseñanza de trabajos mecánicos, artesanías y la música, además de la educación elemental. Los jesuitas tuvieron como propósito fundamental la educación de criollos y españoles; aunque entre ellos hubo quien luchó por dar el mismo nivel de enseñanza a los indios, no lograron su objetivo, y las escuelas que fundaron con este fin no pasaron de la enseñanza del catecismo, la lectura, la escritura, el castellano y algunas veces algo de latín. Los dominicos, que fueron con los franciscanos los que más ardor pusieron en la fundación de escuelas elementales, mantuvieron una posición oficial contra una instrucción de mayor nivel a los indios. Uno de los superiores y más distinguido miembro de la orden de predicadores, fray Domingo de Betanzos, se definía así en torno a la cuestión: "los indios no deben estudiar, porque ningún fruto se puede esperar de su estudio." ${ }^{86}$

84 Ibídem, pág. 146.

85 Buenaventura Delgado, Criado (coordinador): Historia de la educación en España y América, Madrid, 1993, vol. II, págs. 335-337. Para una buena síntesis de la historia del Colegio de Tlatelolco, véase Kobayashi: La educación..., págs. 292-407; y Ocaranza, Fernando: El Imperial Colegio de Indios de la Santa Cruz de Santiago de Tlatelolco, México, 1934.

86 Gallegos Rocafull, Antonio: El pensamiento mexicano en los siglos XVI-XVII, México, 1974, pág. 35. 
La experiencia, no obstante, demostró lo contrario. Cierto es que del Colegio de Tlatelolco no salieron sacerdotes; pero en él se instruyeron historiadores, traductores, retóricos, latinistas, amanuenses y magníficos tipógrafos ${ }^{87}$ como lo evidencia la selecta minoría de indios cuya profesión llegó a ser la de intelectual; recordemos los casos de Fernando de Alva Ixtlixóchilt o Juan Pomar. ${ }^{88}$

Estos éxitos dejaron al descubierto las auténticas razones de los que se oponían a este nivel educativo. No se trataba de una duda sobre la capacidad intectual de los indígenas, sino que creían que para gobernar a los indios con poco esfuerzo lo mejor era dejarlos en una cultura mínima, la necesaria para que fuesen buenos cristianos y obedientes vasallos de la corona castellana. Darles una mayor instrucción, que les permitiera acceder a cargos de responsabilidad en el gobierno de la colonia, como deseaban Zumárraga, Mendoza y otros, era, según los detractores, acelerar el momento de la emancipación total. ${ }^{89}$

En un impresionante texto podemos observar cómo estas artimañas no eran desconocidas para el buen virrey don Antonio de Mendoza, que advertía así a su sucesor:

"Algunos dirán a Vuestra Señoría que los indios son simples y humildes, que no reina malicia ni soberbia en ellos y que no tienen codicia; otros, al contrario, y que están muy ricos y que son vagabundos y que no quieren sembrar. No crea ni a los unos ni a los otros, sino trátese con ellos como con cualquier otra nación, sin reglas especiales, porque pocos hay en estas partes [que] se muevan sin algún interés, ya sea de bienes espirituales o temporales, o pasión o ambición, ora sea vicio o virtud." ${ }^{90}$

\section{Las primeras escrituras manuscritas de indios en América}

Entre las asignaturas de los planes de enseñanza de los indios nunca faltó la escritura; a ésta se le unió en varios centros la asignatura de caligrafía. Tanto en materia escritoria como caligráfica, los indios mostraron una gran habilidad en su uso. "Motolinía" nos da testimonio de ello:

87 Ibídem, pág. 35

88 Alva Ixtlilxochitl fue autor de una Historia de la nación chichimeca (Crónicas de América 11, Historia 16, Madrid, 1985); Juan Pomar llevó a cabo una Relación de Tezcoco (editorial Porrúa, México, 1941).

89 Buenaventura Delgado: Historia de la educación..., vol II, pág. 335; Gil Fernández: "El libro greco-latino...”, pág. 75.

90 Relación, apuntamientos y avisos que por mandado de S.M. dio don Antonio de Mendoza, virrey de Nueva España, a don Luis de Velasco, nombrado para sucederle ente este cargo, sin fecha. CDI, vol. VI, pág. 499. 
"Escribir se enseñaron en breve tiempo, porque en pocos días que escriben luego contrahacen la materia que les dan sus maestros, y si el maestro les manda otra forma de escribir, como es cosa muy común que diversos hombres hacen diversas formas de letras, luego ellos también mudan la letra y la hacen de forma que les da su maestro. En el segundo año que los comenzamos a enseñar dieron a un muchacho de Tezcuco por muestra una bula, y sacola tan al natural, que la letra que hizo parecía el mismo modelo, porque el primer renglón es de letra grande, y abajó sacó la firma ni más ni menos [...] Letras grandes y griegas, puntar y apuntar, así canto llano como canto de órgano, hacen muy liberalmente, y han hecho muchos libros de ello, y también han deprendido a encuadernar e iluminar [...]"91

No fue "Motolinía" el único que se percató de las habilidades caligráficas de los indios; Mendieta también nos ofrece su opinión:

"Después se fueron haciendo muy grandes escribanos en todas las letras, chicas y grandes, quebradas y góticas. Y los religiosos los ayudaron harto a salir escribanos, porque los ocupaban a la continua en escribir libros y tratados que componían o trasuntaban de latín o romance en sus lenguas de ellos [...]"92

Incluso los que estaban en contra de enseñar a los indios, como el escribano Jerónimo López, consejero del virrey, mostraban su admiración:

“[...] tomando los muchachos para mostrar la doctrina [...] luego les quisieron mostrar leer y escribir; por esa habilidad, que es grande, y por lo que el demonio negociador pensaba negociar allí, aprendieron también las letras de escribir libros, puntar e de letras de diversas formas, que es maravilloso verlos." ${ }^{93}$

Con la dominación española, los indígenas continuaron su escritura típica (jeroglífica); pero como con la presencia de los españoles no sólo llegaron objetos nuevos, sino también sonidos, fue preciso traducir a los jeroglíficos indígenas tanto las imágenes como los sonidos; así, por ejemplo, si querían escribir "Mendoza", pintaban un ágave (Metl) y una especie de ratón (tozan), leyendo "Metltozan", es decir, "Mendoza". ${ }^{94}$ A través de este mismo procedimiento los misioneros llegaron a confeccionar catecismos en jeroglíficos.

A la vez, la influencia de la nueva cultura hispana produjo transformaciones en sus códices. En ellos alternarían figuras que representaban signos jeroglíficos y siluetas de personajes, muchas veces a la usanza castellana,

91 Benavente: Historia de los indios..., Tratado III, Capítulo XII, págs. 270-271.

92 Mendieta: Historia Eclesiástica..., Libro IV, Capítulo XIV, págs. 38-39.

93 Gallegos Rocafull: El pensamiento mexicano..., pág. 34.

94 Esteve Barba: "Como empezó América...”, pág. 13. 
con frases en alfabeto latino que contaban y explicaban lo que querían decir los jeroglíficos. Estos códices tenían un formato semejante al de los libros europeos; las hojas se encontraban pegadas, unas contra otras, por sus reversos en blanco, al igual que se hacían en los incunables xilográficos.

Nos han llegado hasta nuestros días bastantes manuscritos realizados por indígenas mexicanos, tanto en lengua nativa como en castellano. Algunos presentan buenas muestras de escritura gótica y semigótica, fruto de la imitación de códices europeos; otros poseen una escritura menos caligráfica, aunque de letra clara con tendencia a la cursividad, sin llegar a tipos avanzados de letra procesal. Hemos de tener en cuenta que los indios, influenciados por la costumbre de expresar sus ideas mediante dibujos, vieron las letras como otras tantas figuras a dibujar, y de ahí su escritura clara, uniforme, suelta, sin el gran número de ligaduras que era común en la escritura de los castellanos, habituados al manejo de la pluma. ${ }^{95}$

\section{A modo de conclusión}

Dos son las ideas que el lector, en nuestra opinión, debería de haber sacado tras la lectura de las páginas precedentes. La primera, que el Nuevo Mundo no fue un espacio marginado ni ajeno a la promoción cultural por parte de la corona castellana. Y segunda, que los indios fueron considerados individuos, personas, seres humanos lo suficientemente dignos y merecedores de una política educativa que entrañaba una enorme cantidad de paciencia, esfuerzo e ilusión en aquellos que, también hombres, hubieron de llevarla a efecto.

95 Millares Carlo, Agustín: Álbum de paleografía hispanoamericana, Barcelona, 1975, pág. 86. 